\title{
Management of Traumatic Prolapsed Uterus in a Crossbred Cow
}

\author{
Pranjal Borah, Maradona Nath* and Dipak Bhuyan \\ Department of ARGO, CVSc, Assam Agricultural University, Khanapara, \\ Guwahati, Assam, India \\ *Corresponding author
}

\begin{abstract}
A B S T R A C T
\section{Keywords}

Traumatic prolapsed uterus, Reposition, Manual method, Buhner's suture, Epidural anesthesia

Article Info

Accepted:

15 January 2019

Available Online:

10 February 2019
\end{abstract}

\section{Introduction}

Peri-parturient complications in dairy cows have direct implications in the post-partum productive and reproductive performance. Post-partum uterine prolapse is one of the serious complication warranting immediate care and veterinary assistance. Uterine prolapse is a common complication of third stage of labor in cow (Arthur et al., 1999). It is characterized by eversion of a part or the whole post - gravid uterus and hanging out of the vulva. Various etiologies were suggested to cause uterine prolapse. Hypocalcaemia causes uterine a tony and delay in involution of cervix predisposes a dairy cow to have uterine prolapse. Forced extraction of fetus causes injuries or irritation of the external birth canal resulted in severe straining can cause a uterine prolapse (Roberts, 1971).Other causes can be retained placenta or a loose uterine attachment in the abdomen due to some inherited genetic factor. The present case study was of complete uterine prolapse with traumatic injuries on the uterine wall in a crossbred cow and its treatment and management.

\section{Materials and Methods}

A pluriparous crossbred cow was handled in field condition with a history of normal 
calving followed by complete expulsion of the uterus at the time of expulsion of foetal membranes, four hours post delivery. The cow was 10 years old and in fourth parity. The cow was exerting abdominal straining intermittently. The prolapsed uterus was hanging out from the vulva and was lying on the dirty floor with severe bleeding due to lacerations. The uterine tissues were moderately edematous, rectal temperature $100.1^{\circ} \mathrm{F}$, rapid respiration and the cow was recumbent with drowsy look.

\section{Results and Discussion}

Epidural anesthesia (2\% Lignocaine hydrochloride) @ $5 \mathrm{ml}$ was injected into the epidural space to desensitize the tail, anus, perineum, vulva and vagina. After proper restraining of the animal the prolapsed mass was lifted above the ischial arch to drain out the urine. Then the uterus was thoroughly cleaned with potassium permanganate solution $(1: 1,000)$ to remove the dirt and dung sticking on it. Icepack was applied over the edematous uterus followed by application of lignocaine gel. The lacerated and slit parts on the uterus were sutured with catgut No.1to check bleeding. Simultaneously intravenous fluid (Intalyte ${ }^{\mathrm{a}} 500 \mathrm{ml}$ and Normal saline solution $500 \mathrm{ml}$ ) was infused to restore the fluid volume. The prolapsed mass was lifted to the level of vulva and gradual repositioning was started from the lateral wall, then the middle wall and the roof. Moderate pressure was applied with palm and the whole organ was positioned by inserting the whole arm into the uterine lumen. Buhner's suture was applied with sterilized nylon ribbon.

After repositioning of the prolapsed mass intravenous fluid therapy was continued with $500 \mathrm{ml}$ of Intacal $^{\mathrm{a}}$ (calcium borogluconate infusion) @ 1 drop/second to revive the muscular tonocity of the uterus and the surrounding structures. To guard the infection
Tefrocef $^{b}$ (ceftiour sodium @ $1.1 \mathrm{mg} / \mathrm{Kg}$ body weight IM for 5 days) was injected. Other supportive therapy includes Intavita ${ }^{\mathrm{a}}$ (6 $\mathrm{ml}$ IM on alternate day for3 occasions), Avilin $^{\mathrm{b}}$ (Pheniramine maleate $22.75 \mathrm{mg} / \mathrm{ml}, 10$ $\mathrm{ml} /$ day IV for 3 days), Feritas ${ }^{\mathrm{a}}$ injection $(5 \mathrm{ml}$ IM on alternate day for 5 occasions) and Lactaid Oral Power ${ }^{\mathrm{b}}$ (40 ml twice daily orally for 30 days). The owner was advised to keep the cow with hind quarter raised and maintain on laxative diet. The cow stood up 3 hours after treatment and took 40 liters of water. There was rapid improvement and nylon ribbon suture was removed $3^{\text {rd }}$ day posttreatment.

In the present case it was observed that the cow started giving straining one hour after delivery and the uterine prolapse occurred four hours post calving. In accordance to the present case Hassan et al., (2010) also observed uterine prolapse immediately or within one hour of calving in crossbred cow. Hypocalcaemia tends to make the uterus atonic and delays the involution of cervix, both of which predispose to uterine prolapse (Roberts, 1971).Similar findings was also reported by Richardson et al., (1981) where they found that mild degree of hypocalcaemia and some degree of dystocia was associated with the uterine prolapse in beef cattle. Moderate hypocalcaemic symptoms like trembling, muscle tremor and inability to raise was also observed in the present study as stated by earlier workers.

Hypocalcaemia may occurred due to improper nutrition at the transition phase of the cow. Kaneko and Cornelius (1970) indicated that estrogen depress the serum calcium level while simultaneously increasing serum phosphorus level leading to hypocalcaemia. The prognosis of uterine prolapse varies depending on the time taken to handle the case and degree of damage to the prolapsed mass. Jubbs et al., (1990) and Murphy and 
Dobson (2002) reported 73.50 and 80.00 per cent survivality rates in uterine prolapse cases respectively. An investigation by Ishii et al., (2010) on 76 uterine prolapse cases found that replacing the uterus by raising the hind legs during the treatment could improve the

\section{References}

Arthur, G.H., Noakes, D.E and Pearson, H. (1999). Veterinary reproduction and Obstetrics. $\quad 7^{\text {th }}$ edition, Saunders Company Ltd., Philadelphia, PA, WB.

Hassan, M.M., Shuvo, K.B., Khan, S.A., Elahi, M.F., Mony, T.J. and Roy, K. (2010). Correction and Management of uterine prolapse and retained placenta in cows at Faridpur, Bangladesh. Intas Polivet. 11 (1): 1619.

Jubb, T.F., Malmo, J., J. Brightling, P. and Davis, G.M. (1990). Survival and fertility after uterine prolapsed in dairy cows. Australian Veterinary Journal. 67: 22-24. recovery rate and post treatment breeding performance.

Prompt recovery observed in the present case might be due to immediate veterinary care provided to the cow.

Kaneko, J.J. and C.E. Cornelius (1970). Clinical Biochemistry of Domestic Animals. $2^{\text {nd }}$ Edition. Vol. 1. Pp. 322323. New York: Academic Press.

Murphy, A.M. and Dobson, H. (2002). Predisposition, subsequent fertility and mortality of cows with uterine prolapsed. Veterinary Record. 151: 733-35.

Richardson, G.F., Klemer, A.D. and Knudsen, D.B. (1981). Observation on uterine prolapse in beef cattle. Can. Vet. J. 22: 189-191.

Roberts, S.J (1971). Veterinary Obstetrics and Genital Diseases. $2^{\text {nd }}$ Edition, CBS Publishers and Distributors, New Delhi, pp189, 205, 235, 308 and 456.

\section{How to cite this article:}

Pranjal Borah, Maradona Nath and Dipak Bhuyan. 2019. Management of Traumatic Prolapsed Uterus in a Crossbred Cow. Int.J.Curr.Microbiol.App.Sci. 8(02): 1960-1962. doi: https://doi.org/10.20546/ijcmas.2019.802.228 